\title{
Comparison of the effects of ispaghula and wheat bran on rat caecal and colonic fermentation
}

\author{
C A Edwards, M A Eastwood
}

\begin{abstract}
The effects of ispaghula and wheat bran on the contents of the caecum and proximal and distal colon of the rat were investigated to identify any differences that might account for their effects on colonic motility. Rats fed diets supplemented with $5 \%$ ispaghula and $10 \%$ wheat bran for 28 days were killed and the contents of the gut collected. Caecal and colonic content wet and dry weight and short chain fatty acid (SCFA) content were measured. In additional in vitro fermentations in batch cultures of mixed rat caecal bacteria with ispaghula and bran, SCFA production was monitored over 24 hours. Both ispaghula and wheat bran increased faecal weight but ispaghula was more effective. Ispaghula resulted in greater and more liquid contents, with a characteristic pattern of SCFA production (higher propionic acid) maintained throughout the colon. In contrast, wheat bran affected only the caecum and faeces. SCFA content and wet and dry weight in the proximal and distal colon were unaffected by wheat bran. Caecal butyrate was characteristically higher in wheat bran fed rats but ispaghula produced higher butyrate in the distal colon. In contrast, ispaghula seemed to be fermented more quickly in vitro than wheat bran. Thus, wheat bran has a portion that is rapidly fermented and an inert residue that may stimulate motility. Ispaghula seems to be fermented throughout the colon but maintains a high water content which dilutes the luminal contents.
\end{abstract}

(Gut 1992; 33: 1229-1233)

Ispaghula and wheat bran are both effective stool bulkers and both relieve the symptoms of diverticulosis. Diverticulosis is thought to be associated with high colonic pressure and this pressure is believed to be undesirable. 'Wheat bran decreases colonic pressure but ispaghula actually increases it, ${ }^{2}$ a fact that would contradict its use in the treatment of diverticular disease and in any other conditions where an increase in colonic pressure may cause particular problems.

The colon has three functional units. The proximal colon seems to be a reservoir and fermentation chamber where motility patterns probably act to retain material in the proximal colon. The transverse colon acts to move material along to the rectum and may be important in the absorption of water and the formation of the stool. The rectum acts as a storage organ to contain stool until the bowel is evacuated. The motility patterns which allow the different regions of the colon to act in these separate ways are complex and it is difficult to study them. The luminal factors which stimulate or inhibit contraction are unknown. The physical properties of the luminal contents may act to stimulate motility. Gas or large volumes of fluid may induce propulsive contractions, ${ }^{3}$ but viscous contents may resist the action of intestinal contractions as they do in the small intestine. The presence of a rich bacterial flora in the colon gives rise to many products that may stimulate or inhibit colonic motility. These include secondary bile acids, ${ }^{5}$ hydroxy fatty acids, ${ }^{6}$ and short chain fatty acids (SCFA).

Differences in the fermentation site and rate of ispaghula and bran may account for their different effects on colonic motility and hence pressure.

This study compared the effects of bran and ispaghula on the luminal contents of the caecum and proximal and distal colon and faeces of the rat to identify differences that may account for their effect on motility. In addition, the fermentation of bran and ispaghula was studied in vitro.

\section{Methods}

\section{RAT STUDIES}

Forty male wistar rats (weighing approximately $150 \mathrm{~g}$ ) were fed a basal diet containing $4 \cdot 5 \mathrm{~g} / 100 \mathrm{~g}$ non-starch polysaccharide (NSP), $2.99 \mathrm{~g} / 100 \mathrm{~g}$ digestible fat, $12.9 \mathrm{~g} / 100 \mathrm{~g}$ digestible protein,
Gastrointestinal Laboratory, Western General Hospital, Edinburgh

C A Edwards

M A Eastwood

Correspondence to:

DrC A Edwards, Departmen of Human Nutrition, Yorkhill Hospitals, Glasgow G3 8SJ .

Accepted for publication 20 December 1991
TABLE I Sugar composition of dietary fibre in rat diets (values, $g / 100 \mathrm{~g}$ dry weight)

\begin{tabular}{|c|c|c|c|c|c|c|c|c|c|c|}
\hline & \multirow[b]{2}{*}{ Cellulose } & \multicolumn{8}{|c|}{ Non-cellulose polysaccharides } & \multirow[b]{2}{*}{ Total } \\
\hline & & Rha & $F u c$ & Ara & $X y l$ & Man & Gal & Glu & UAC & \\
\hline \multicolumn{11}{|l|}{ Basal diet: } \\
\hline Soluble & - & $\mathrm{t}$ & $\mathrm{t}$ & $0 \cdot 2$ & $\mathrm{t}$ & $0 \cdot 1$ & 0.4 & $0 \cdot 2$ & 0.5 & $1 \cdot 4$ \\
\hline Insoluble & - & $0 \cdot 1$ & $0 \cdot 1$ & 0.5 & 0.3 & 0.1 & 0.7 & 0.9 & 0.4 & $3 \cdot 1$ \\
\hline \multicolumn{11}{|l|}{ Wheat bran: } \\
\hline Soluble & - & $\mathrm{t}$ & $\mathrm{t}$ & $0 \cdot 7$ & $2 \cdot 3$ & $\mathrm{t}$ & $0 \cdot 3$ & 0.9 & 0.6 & $4 \cdot 8$ \\
\hline Insoluble & $10 \cdot 5$ & $\mathrm{t}$ & $i$ & $9 \cdot 6$ & $16 \cdot 8$ & $0 \cdot 3$ & 0.6 & $2 \cdot 4$ & $1 \cdot 3$ & $+1 \cdot 5$ \\
\hline \multicolumn{11}{|l|}{ Ispaghula: } \\
\hline Soluble & - & $3 \cdot 0$ & $\mathrm{t}$ & $10 \cdot 6$ & $+2 \cdot 3$ & $0 \cdot 3$ & $2 \cdot 0$ & 0.9 & $5 \cdot 8$ & $6+\cdot 9$ \\
\hline Insoluble & $7 \cdot 0$ & $\mathrm{t}$ & $\mathrm{t}$ & $9 \cdot 7$ & $14 \cdot 4$ & 0.9 & $2 \cdot 4$ & $\mathrm{t}$ & $0 \cdot 3$ & $34 \cdot 7$ \\
\hline
\end{tabular}

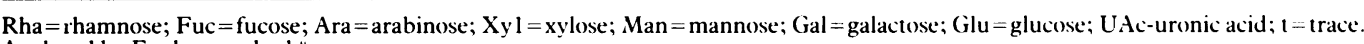
Analysed by Englyst method." 
$62.95 \mathrm{~g} / 100 \mathrm{~g}$ starch, $22.8 \mathrm{~g} / 100 \mathrm{~g}$ sugar (supplied by Special Diet, Services Ltd, Witham, Essex $)^{8}$ for 28 days. The diet was then supplemented with either 5\% ispaghula (Richardson and Vicks Ltd, Egham, UK) in 10 rats, $10 \%$ coarse wheat bran (95\%) passed through sieve apparatus $1 \cdot 5-0.5$ $\mathrm{mm}$, Chancelot Mills Ltd, Edinburgh, UK in 10

TABLE II Effect of ispaghula and wheat bran on the body weight, faecal output, and caecal and colonic tissue weights of rats

\begin{tabular}{|c|c|c|c|c|c|c|}
\hline & \multicolumn{2}{|l|}{$\begin{array}{l}\text { Ispaghula } \\
(n=10)\end{array}$} & \multicolumn{2}{|l|}{$\begin{array}{l}\begin{array}{l}\text { Bran } \\
(n=10)\end{array} \\
\end{array}$} & \multicolumn{2}{|l|}{$\begin{array}{l}\text { Basal } \\
(n=20)\end{array}$} \\
\hline & (Mean & $(S E M))$ & (Mean & $(S E M))$ & (Mean & $(S E M))$ \\
\hline $\begin{array}{l}\text { Final body weight }(\mathrm{g}) \\
\text { Faecal output }(\mathrm{g} / \mathrm{d}):\end{array}$ & 349 & (6) & 363 & (12) & 364 & (8) \\
\hline $\begin{array}{l}\text { Wecal output (g/a): } \\
\text { Wet weight } \\
\text { Dry weight }\end{array}$ & $\begin{array}{l}7 \cdot 9^{\star \star \star} \\
2 \cdot 8^{\star \star \star}\end{array}$ & $\begin{array}{l}(0 \cdot 5) \\
(0 \cdot 2)\end{array}$ & $\begin{array}{l}5 \cdot 4^{\star \star} \\
2 \cdot 0^{\star \star}\end{array}$ & $\begin{array}{l}(0 \cdot 6) \\
(0 \cdot 1)\end{array}$ & $\begin{array}{l}3 \cdot 15 \\
1 \cdot 51\end{array}$ & $\begin{array}{l}(0 \cdot 2) \\
(0 \cdot 1)\end{array}$ \\
\hline $\begin{array}{l}\text { Caecal tissue weight } t \\
\text { (g/kg body weight) }\end{array}$ & $3 \cdot 3^{\star \star \star}$ & $(0 \cdot 3)$ & $2 \cdot 2$ & $(0 \cdot 1)$ & $2 \cdot 1$ & $(0 \cdot 1)$ \\
\hline $\begin{array}{l}\text { Proximal colon tissue weight } \dagger \\
\text { (g/kg body weight })\end{array}$ & $3 \cdot 0^{\star \star \star}$ & $(0 \cdot 1)$ & $2 \cdot 2^{\star}$ & $(0 \cdot 1)$ & $2 \cdot 0$ & $(0 \cdot 1)$ \\
\hline $\begin{array}{l}\text { Distal colon tissue weight }(\dagger) \\
(\mathrm{g} / \mathrm{kg} \text { body weight })\end{array}$ & $3 \cdot 0^{\star \star \star}$ & $(0 \cdot 1)$ & $2 \cdot 4$ & $(0 \cdot 1)$ & $2 \cdot 2$ & $(0 \cdot 1)$ \\
\hline
\end{tabular}

Ispaghula and wheat bran fed rats were compared with basal diet rats by Student's $t$ test after one way analysis of variance. ${ }^{\star} \mathrm{p}<0 \cdot 5,{ }^{\star} \mathrm{p}<0 \cdot 1,{ }^{\star \star \star} \mathrm{p}<0.001$.

The basal diet contained $4.5 \mathrm{~g} / 100 \mathrm{~g}$ non-cellulose polysaccharides.

t This does not include the weight of contents.

TABLE III Wet and dry weight of caecal and colonic contents of rats fed basal diets supplemented with $5 \%$ ispaghula or $10 \%$ wheat bran

\begin{tabular}{|c|c|c|c|c|c|c|}
\hline \multirow[b]{2}{*}{ Gut content ( $g$ ) } & \multicolumn{2}{|c|}{ Ispaghula } & \multicolumn{2}{|l|}{ Bran } & \multicolumn{2}{|l|}{ Basal } \\
\hline & (Mean & $(S E M))$ & (Mean & $(S E M))$ & (Mean & $(S E M))$ \\
\hline \multicolumn{7}{|l|}{ Caecum: } \\
\hline Wet weight & $7 \cdot 53^{\star \star \star}$ & $(0 \cdot 39)$ & $3 \cdot 77$ & $(0 \cdot 23)$ & $3 \cdot 78$ & $(0 \cdot 7)$ \\
\hline Dry weight & $1 \cdot 03^{\star \star \star}$ & $(0.04)$ & $0 \cdot 70$ & $(0.06)$ & 0.75 & $(0.04)$ \\
\hline \multicolumn{7}{|l|}{ Proximal colon: } \\
\hline Wet weight & $1 \cdot 92^{\star \star \star}$ & $(0 \cdot 2)$ & 0.68 & $(0 \cdot 17)$ & $0 \cdot 5$ & $(0 \cdot 11)$ \\
\hline Dry weight & $0 \cdot 32$ & $(0.03)$ & $0 \cdot 21$ & $(0.05)$ & $0 \cdot 19$ & $(0.04)$ \\
\hline \multicolumn{7}{|l|}{ Distal colon: } \\
\hline Wet weight & $2 \cdot 55^{\star \star \star}$ & $(0 \cdot 2)$ & 1.06 & $(0 \cdot 27)$ & $1 \cdot 33$ & $(0 \cdot 14)$ \\
\hline Dry weight & 0.79 & $(0.06)$ & 0.49 & $(0 \cdot 13)$ & 0.61 & $(0.07)$ \\
\hline
\end{tabular}

Ispaghula and wheat bran fed rats were compared with basal diet rats by Student's $t$ test after one way analysis of variance. ${ }^{\star \star \star} \mathrm{p}<0.001$.

TABLE IV Percentage of water in caecal and colonic contents and faeces of rats fed a basal diet supplemented with $5 \%$ ispaghula or $10 \%$ wheat bran

\begin{tabular}{|c|c|c|c|c|c|c|}
\hline & \multicolumn{2}{|l|}{ Ispaghula } & \multicolumn{2}{|l|}{ Bran } & \multicolumn{2}{|l|}{ Basal } \\
\hline & (Mean & $(S E M))$ & (Mean & $(S E M))$ & (Mean & $(S E M))$ \\
\hline $\begin{array}{l}\text { Caecum } \\
\text { Proximal colon } \\
\text { Distal colon } \\
\text { Faeces }\end{array}$ & $\begin{array}{l}86 \cdot 2^{\star \star \star} \\
82 \cdot 4^{\star \star \star} \\
69 \cdot 0^{\star \star} \\
65 \cdot 9^{\star \star \star}\end{array}$ & $\begin{array}{l}(0 \cdot 6) \\
(1 \cdot 1) \\
(1 \cdot 3) \\
(0 \cdot 9)\end{array}$ & $\begin{array}{l}81 \cdot 5 \\
68 \cdot 2 \\
53 \cdot 9 \\
52 \cdot 0\end{array}$ & $\begin{array}{l}(0.7) \\
(1.9) \\
(2.4) \\
(2.5)\end{array}$ & $\begin{array}{l}80 \cdot 2 \\
64 \cdot 2 \\
55 \cdot 9 \\
52 \cdot 0\end{array}$ & $\begin{array}{l}(0 \cdot 4) \\
(2 \cdot 0) \\
(1 \cdot 6) \\
(1 \cdot 0)\end{array}$ \\
\hline
\end{tabular}

Ispaghula and wheat bran fed rats were compared with basal fed rats by Student's $t$ test after one way analysis of variance. ${ }^{\star \star} \mathrm{p}<0.01,{ }^{\star \star \star} \mathrm{p}<0.001$.

TABLE V Short chain fatty acid (SCFA) content of the caecum, colon, and faeces of rats fed a basal diet supplemented with $10 \%$ wheat bran or $5 \%$ ispaghula

\begin{tabular}{|c|c|c|c|c|c|c|}
\hline & \multicolumn{2}{|l|}{ Basal } & \multicolumn{2}{|l|}{ Bran } & \multicolumn{2}{|l|}{ Ispaghula } \\
\hline & (Mean & $(S E M))$ & (Mean & $(S E M))$ & (Mean & $(S E M))$ \\
\hline \multirow{8}{*}{$\begin{array}{l}\text { Caecal SCFA: } \\
\mu \mathrm{mol} / \mathrm{g} \text { dry weight } \\
\mu \mathrm{mol} / \mathrm{g} \text { wet weight } \\
\mu \mathrm{mol} / \mathrm{caecum} \\
\text { Proximal colon: } \\
\mu \mathrm{mol} / \mathrm{g} \text { dry weight } \\
\mu \mathrm{mol} / \mathrm{g} \text { wet weight } \\
\mu \mathrm{mol} \text { total }\end{array}$} & \multicolumn{2}{|l|}{$(n=20)$} & \multicolumn{2}{|l|}{$(n=10)$} & \multicolumn{2}{|l|}{$(n=10)$} \\
\hline & \multirow{4}{*}{$\begin{array}{c}441 \cdot 0 \\
87 \cdot 3 \\
334 \cdot 0 \\
(n=12)\end{array}$} & $(17 \cdot 9)$ & \multirow{4}{*}{$\begin{array}{c}380 \\
71 \cdot 3^{\star} \\
272 \\
(n=8)\end{array}$} & $(23 \cdot 4)$ & $517^{\star}$ & $(26 \cdot 7)$ \\
\hline & & $(3.9)$ & & $(6 \cdot 1)$ & $70 \cdot 4 \star \star \star$ & $(2 \cdot 2)$ \\
\hline & & $(26 \cdot 5)$ & & $(32 \cdot 2)$ & $532^{\star \star \star}$ & $(34 \cdot 6)$ \\
\hline & & & & & $(n=10)$ & \\
\hline & 201 & $(16 \cdot 5)$ & 218 & $24 \cdot 9$ & $326^{\star \star}$ & $(20 \cdot 2)$ \\
\hline & $69 \cdot 9$ & $(4 \cdot 2)$ & $71 \cdot 1$ & $11 \cdot 1$ & $56 \cdot 2$ & $(4 \cdot 6)$ \\
\hline & $47 \cdot 9$ & $(9 \cdot 0)$ & $52 \cdot 5$ & $12 \cdot 0$ & $103 \cdot 6^{\star \star \star}$ & $(8 \cdot 3)$ \\
\hline Distal colon: & $(n=18)$ & & $(n=9)$ & & $(n=10)$ & \\
\hline$\mu \mathrm{mol} / \mathrm{g}$ dry weight & $158 \cdot 5$ & $(15 \cdot 7)$ & $120 \cdot 4$ & $(12 \cdot 1)$ & 180 & $(16 \cdot 4)$ \\
\hline$\mu \mathrm{mol} / \mathrm{g}$ wet weight & 68.9 & $(6 \cdot 6)$ & $57 \cdot 9$ & $(2 \cdot 8)$ & 54.9 & $(4 \cdot 3)$ \\
\hline umol total & $88 \cdot 0$ & $(8 \cdot 5)$ & $76 \cdot 1$ & $(17 \cdot 3)$ & $137 \cdot 1^{\star \star}$ & $(12 \cdot 0)$ \\
\hline Faeces: & $(n=20)$ & & $(n=10)$ & & $(n=9)$ & \\
\hline$\mu \mathrm{mol} / \mathrm{g}$ dry weight & $87 \cdot 2$ & $(7 \cdot 2)$ & $105 \cdot 2$ & $(9 \cdot 8)$ & $212 \cdot 4^{\star \star \star \star}$ & $(12 \cdot 8)$ \\
\hline$\mu \mathrm{mol} / \mathrm{g}$ wet weight & $\begin{array}{r}42.9 \\
127.4\end{array}$ & $(3 \cdot 0)$ & $54 \cdot 3$ & $(5 \cdot 8)$ & $78 \cdot 5^{\star \star}$ & $(5 \cdot 5)$ \\
\hline$\mu \mathrm{mol}$ & $127 \cdot 4$ & $(11 \cdot 4)$ & $287^{\star}$ & $(51 \cdot 3)$ & $572 \cdot 6^{\star \star \star}$ & $(5+\cdot 7)$ \\
\hline
\end{tabular}

Results of ispaghula and bran fed rats were compared with basal rats by Student's $t$ test after one way analysis of variance. ${ }^{\star} \mathrm{p}<0 \cdot 05,{ }^{\star \star} \mathrm{p}<0 \cdot 01,{ }^{\star \star \star} \mathrm{p}<0 \cdot 001, \mathrm{n}=$ no of samples. rats, or fed unsupplemented to 20 rats for a further 28 days. The ispaghula and wheat bran were analysed by the Englyst method" (Table I) and shown to be $99.6 \%$ and $46.3 \%$ non-starch polysaccharide respectively.

The animals were then placed in metabolic cages for three days to allow collection of faeces. At the end of this period the rats were killed and the caecum and colon were removed. Colonic length was measured and the colon divided into two equal halves - the proximal and distal colon. After removal of fat, each colonic section was weighed, the contents carefully removed, and the tissue rinsed in $0.9 \%$ saline, blotted, and reweighed. The contents were then weighed separately, their $\mathrm{pH}$ was brought to $\mathrm{pH} 9$ with $\mathrm{NaOH}$, they were freeze dried, and then reweighed. The SCFA content of each section of the colon was measured by gas liquid chromatography. ${ }^{10}$

\section{STATISTICAL ANALYSIS}

Results from the rat studies were compared by one way analysis of variance and Student's $t$ test.

\section{IN VITRO FERMENTATION}

Ten incubations were carried out using the pooled contents of three rat caeca. These rats had been previously fed the standard diet (CRMX Labsure Ltd, $13 \cdot 3 \%$ NSP). The basal medium consisted of basic salts and mineral mixes, tryptone as an amino acid source, and cysteine $\mathrm{HCl}$ and sodium sulphide as a reducing agent." The carbohydrate was either $0.5 \mathrm{~g}$ ispaghula husk (Richardson and Vicks Ltd UK) $(n=4)$ or $0.5 \mathrm{~g}$ predigested coarse bran (Chancelot Mills Ltd, Edinburgh UK) $(n=4)$. The bran had been predigested with amylase and amyloglucosidase to remove any contaminating starch. Two cultures were incubated without a carbohydrate source to act as control. Ten culture vessels containing $40 \mathrm{ml}$ medium were gassed with $95 \% \mathrm{~N} / 5 \% \mathrm{CO}_{2}$ until the reazurin indicator in the medium became colourless. Each vessel was then seeded with $2 \mathrm{ml}$ of the inoculum and kept under constant gas pressure to maintain anaerobic conditions at $37^{\circ} \mathrm{C}$ in a shaking water bath.

Sample of culture fluid were taken at one, four, six, and 24 hours for analysis of SCFA.

\section{Results}

\section{RAT STUDY}

Both ispaghula and bran increased the wet and dry faecal weights (Table II) but ispaghula was more effective. Ispaghula increased the wet content of all parts of the colon by over $100 \%$ (Table III) but significantly increased the dry content only in the caecum (Table IV). This resulted in a greater and more liquid colonic content in the ispaghula fed animals (Table IV).

Ispaghula increased the total SCFA concentration in the proximal colon and faeces as expressed per $g$ dry weight in contrast to bran (Table V) but since ispaghula also increased the water content in the proximal colon, the concen- 
TABLE VI Pattern of short chain fatty acids (molar proportions) in the caecum, colon, and faeces of rats fed a basal diet supplemented with 10\% wheat bran or 5\% ispaghula

\begin{tabular}{|c|c|c|c|c|c|c|}
\hline & \multicolumn{2}{|l|}{ Basal } & \multicolumn{2}{|l|}{ Bran } & \multicolumn{2}{|c|}{ Ispaghula } \\
\hline & (Mean & $(S E M))$ & (Mean & $(S E M))$ & (Mean & $(S E M))$ \\
\hline Caecum: & $(n=20)$ & & $(n=10)$ & & $(n=10)$ & \\
\hline Acetic & 645 & $(11 \cdot 8)$ & $582^{\star \star}$ & $(11 \cdot 1)$ & 626 & $(11 \cdot 8)$ \\
\hline Propionic & 178 & $(9 \cdot 4)$ & $150^{\star}$ & $(6 \cdot 1)$ & $216^{\star \star}$ & $(7 \cdot 3)$ \\
\hline Nbutyric & 141 & $(10 \cdot 0)$ & $232^{\star \star \star}$ & $(13 \cdot 7)$ & 129 & $(14 \cdot 7)$ \\
\hline Isobutyric & 15 & $(1.7)$ & 17 & $(2 \cdot 0)$ & 12 & $(1 \cdot 7)$ \\
\hline Valeric & 20 & $(2 \cdot 0)$ & 16 & $(0 \cdot 6)$ & 14 & $(3 \cdot 3)$ \\
\hline Isovaleric & 5 & $(0 \cdot 7)$ & 5 & $(1 \cdot 1)$ & 2 & $(0 \cdot 5)$ \\
\hline Proximal colon: & $(n=20)$ & & $(n=8)$ & & $(n=10)$ & \\
\hline Acetic & 711 & $(15 \cdot 9)$ & 723 & $(11 \cdot 5)$ & 684 & $(34 \cdot 5)$ \\
\hline Propionic & 152 & $(7 \cdot 2)$ & 123 & $(9 \cdot 2)$ & $227^{\star \star \star}$ & $(22 \cdot 1)$ \\
\hline Nbutyric & 84 & $(5 \cdot 8)$ & 123 & $(16 \cdot 7)$ & 106 & $(20 \cdot 9)$ \\
\hline Isobutyric & 14 & $(3 \cdot 6)$ & 11 & $(1 \cdot 3)$ & 7 & $(1.9)$ \\
\hline Valeric & 29 & $(7 \cdot 7)$ & 17 & $(1.5)$ & 11 & $(2 \cdot 3)$ \\
\hline Isovaleric & 10 & $(2 \cdot 6)$ & 6 & $(1.8)$ & 4 & $(1 \cdot 4)$ \\
\hline Distal colon: & $(n=18)$ & & $(n=9)$ & & $(n=10)$ & \\
\hline Acetic & 758 & $(17 \cdot 6)$ & 794 & $(26 \cdot 5)$ & 719 & $(24 \cdot 9)$ \\
\hline Propionic & 108 & $(11 \cdot 2)$ & 82 & $(9 \cdot 1)$ & $158^{\star}$ & $(17 \cdot 4)$ \\
\hline Nbutyric & 72 & $(7 \cdot 6)$ & 85 & $(19 \cdot 4)$ & $101^{\star \star \star}$ & $(9 \cdot 1)$ \\
\hline Isobutyric & 16 & $(1 \cdot 3)$ & 11 & $(2 \cdot 9)$ & 4 & $(1 \cdot 4)$ \\
\hline Valeric & 36 & $(10 \cdot 2)$ & 20 & $(2 \cdot 5)$ & 12 & $(1 \cdot 3)$ \\
\hline Isovaleric & 13 & $(2 \cdot 3)$ & 9 & $(2 \cdot 5)$ & 5 & $(1 \cdot 0)$ \\
\hline Faeces: & $(n=20)$ & & $(n=10)$ & & $(n=9)$ & \\
\hline Acetic & 796 & $(13 \cdot 9)$ & 788 & $(16 \cdot 4)$ & $693^{\star \star \star}$ & $(14 \cdot 5)$ \\
\hline Propionic & 97 & $(5: 6)$ & 105 & $(7 \cdot 2)$ & $171^{\star \star \star}$ & $(6 \cdot 9)$ \\
\hline Nbutyric & 49 & $(13 \cdot 6)$ & 77 & $(12 \cdot 1)$ & $111^{\star \star}$ & $(7 \cdot 6)$ \\
\hline Isobutyric & 29 & $(7 \cdot 6)$ & 13 & $(2 \cdot 1)$ & 8 & $(1.8)$ \\
\hline Valeric & 14 & $(1 \cdot 7)$ & 12 & $(2 \cdot 2)$ & 12 & $(2 \cdot 0)$ \\
\hline Isovaleric & 14 & $(1 \cdot 3)$ & $6^{\star \star}$ & $(1 \cdot 1)$ & $5^{\star \star \star}$ & $(1 \cdot 5)$ \\
\hline
\end{tabular}

Rats fed ispaghula or wheat bran were compared with basal fed rats by Student's $t$ test after one way analysis of variance. ${ }^{\star} p<0 \cdot 05,{ }^{\star \star} p<0 \cdot 01,{ }^{\star \star \star} p<0 \cdot 001, n=$ no of samples.

tration per $\mathrm{g}$ wet weight was similar to that of the bran fed or control rats (Table V)

Ispaghula, however, had the highest concentration in the faeces and had the highest total amount of SCFAs in each part of the colon (Table V). There was no significant difference between the SCFA concentrations of bran and control diet fed rats at any point in the colon but since bran increased faecal output, the total faecal SCFA output for bran was higher than that for control (Table V). The patterns of SCFAs produced by bran and ispaghula in the caecum reflected those produced in the in vitro fermentations (Table VI), with more propionic acid produced in the ispaghula group and more butyric acid in the bran group.

The pattern of SCFAs in the colon and faeces of the bran fed rats was no different from that of the control fed rats whereas rats fed ispaghula had a greater proportion of propionic acid throughout the colon and in the faeces. In fact the ispaghula fed rats had the highest distal colonic

chain fatty acid

concentration in batch

cultures of mixed rat caecal

bacteria with ispaghula and

predigested wheat bran.

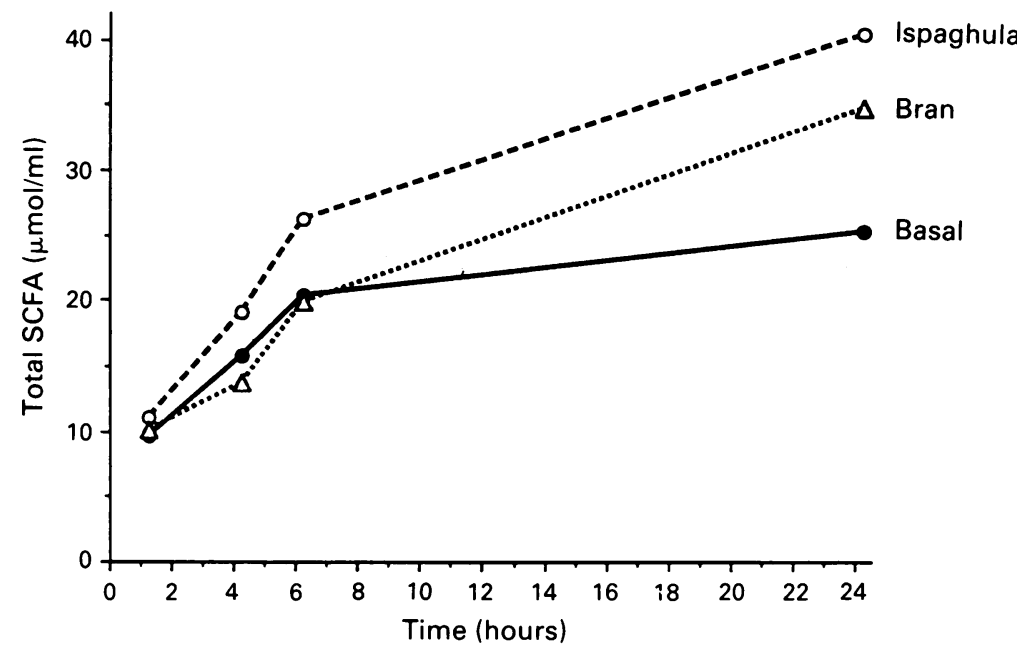

and faecal butyric acid molar proportions (Table VI).

\section{TISSUE WEIGHTS}

Ispaghula also increased the tissue wet weight of all regions of the colon whereas bran had very little effect on this (Table II).

\section{IN VITRO FERMENTATION}

Ispaghula was fermented at a faster rate in vitro than bran. Figures 1 and 2 show the total SCFA and propionic and butyric acid concentrations in the cultures at one, four, six, and 24 hours. Ispaghula fermentation was characterised by an increase in the total SCFA concentration, and in particular in propionic acid production after four hours, whereas bran fermentation was characterised by a higher butyric acid concentration, but only at 24 hours; the increase occurring between six and 24 hours.

\section{Discussion}

In this study we aimed to identify differences in the luminal contents of the caecum and colon of rats fed either ispaghula or bran that may be related to the effects of these fibre supplements on colonic motility and pressure. Ten per cent bran supplementation was compared with 5\% ispaghula since only approximately $50 \%$ of wheat bran is dietary fibre. There was no significant difference in the food intake of the five rats fed each of the diets over a three day period. In the in vitro studies, the bran was predigested to remove contaminating starch. The physical properties of the caecal and colonic luminal contents of rats fed ispaghula were very different from those of rats fed wheat bran and the control diet. Not only were the colons of the ispaghula fed rats fuller, especially the proximal colon, but a high water content was maintained throughout the colon, in contrast to the control and bran fed rats in whom substantial amounts of water had already been removed by the proximal colon and whose faeces were only $52 \%$ water.

This difference in the colonic contents of the rats fed bran and ispaghula suggests that bran may stimulate propulsion and therefore reduce colonic transit time whereas ispaghula may simply increase the flow of contents through the colon. This proposal would agree with studies that have not shown an acceleration of transit by ispaghula. ${ }^{12}$ Transit time was not measured in this study. The rate and pattern of fermentation of the two fibres was also very different.

The SCFA profiles produced in the in vitro fermentations resembled the caecal SCFA profiles for both fibres, with ispaghula showing a high propionic acid and bran a high butyric acid production. The high propionate content was maintained throughout the colon of the ispaghula fed rats but the high butyrate production of bran fermentation was not maintained outside the caecum.

Although in vitro, bran seemed to be fermented more slowly than ispaghula, it seems that its fermentation is mainly completed in the caecum of the rat. The SCFA profile of ispaghula 

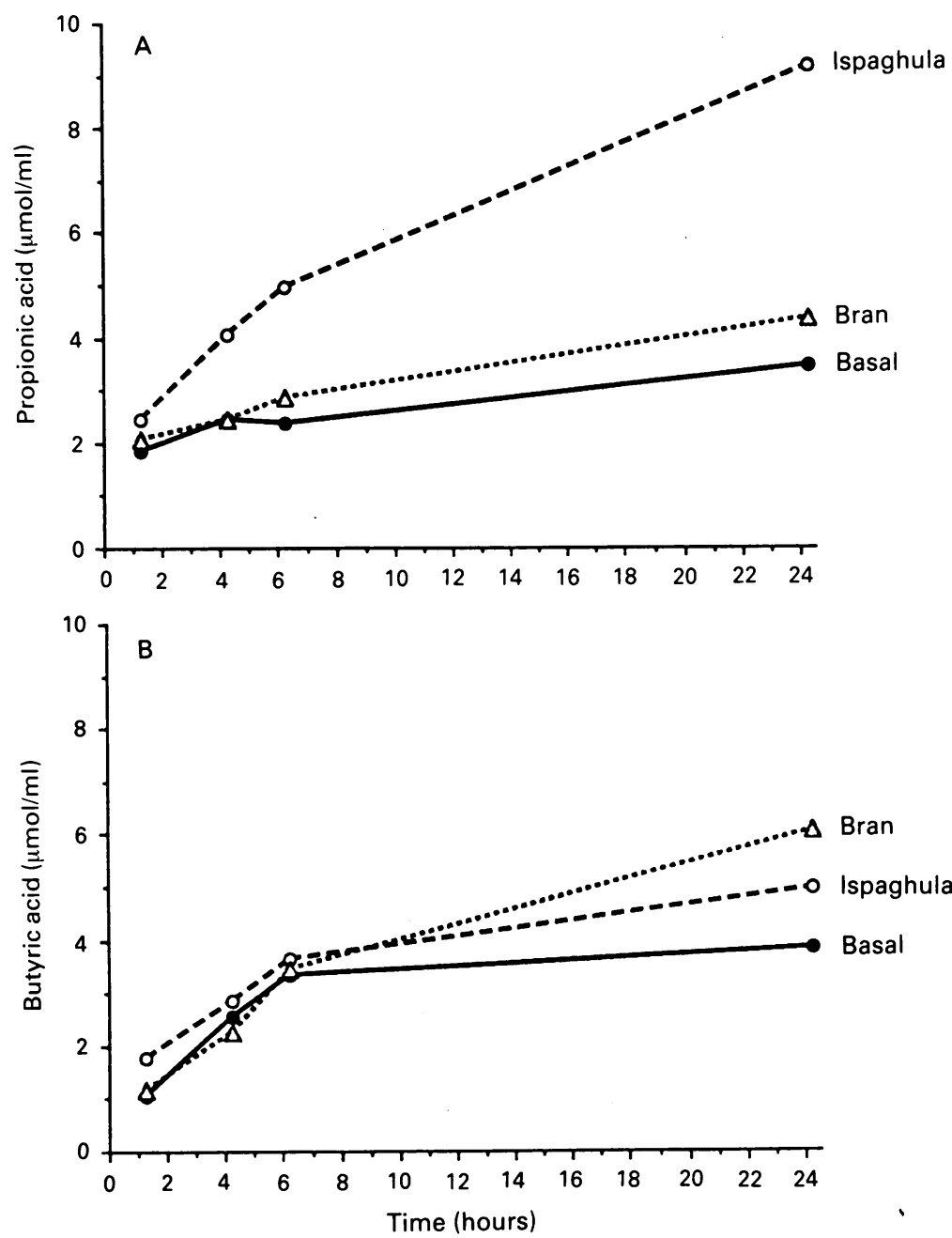

Figure 2: Mean proprionic and butyric acid concentration in batch cultures of mixed rat caecal bacteria with ispaghula and predigested wheat bran. and in vivo animal models ${ }^{1 \times}$ using different parts of the colon.

If the SCFA concentration has an effect on motility then there would be no difference between the bran and the ispaghula. However, contact area may be more important than concentration since we have previously shown that low concentrations of deoxycholic acid provoke motility responses in the human colon if given in a large ${ }^{19}$ rather than a small volume The distension caused by the much larger luminal content throughout the colon in rats fed ispaghula may be a more significant stimulus for propulsion.

The biological effect of the different amounts of propionic and butyric acids produced by ispaghula and bran are unknown but may be important if different acids have different potency. In view of the continued interest in the action of butyrate on the colonic epithelia, ${ }^{21} \cdot 1$ it is of interest that, of the diets studied, ispaghula had the highest amount of butyrate reaching the distal colon. The final SCFA patterns produced in the in vitro cultures resembled those in the rat caecum but the timed samples suggested that ispaghula was fermented more rapidly than wheat bran, in fact that was not evident in vivo. This indicates the limitations of using in vitro batch cultures to predict events in vivo.

In conclusion, this study has shown that ispaghula is more rapidly fermented in vitro but in vivo, wheat bran seems to affect caecal fermentation only and the residue then acts as an inert fibre that may stimulate motility by its physical presence, perhaps by stimulation of multimodal mechanoreceptors." Ispaghula, in contrast, seems to be fermented throughout the colon and maintains a high water content in the lumen which dilutes the SCFA content to levels similar to those found in bran supplemented or a low fibre diet. The biggest differences between ispaghula and the other diets were seen in the proximal colon and this may be an area of the colon that warrants further study with regard to its effects on transit and motility.

The authors thank Proctor \& Gamble Co for its financial support

1 Painter NS. Diverticular disease of the colon. London: Heinemann, 1975.

2 Eastwood MA, Smith AN, Brvdon WG, Pritchard J Comparison of bran, ispaghula and lactulose on colon function in diverticular disease. (iut 1978; 19:11+1-7.

3 Chauve A, Devroede G, Bastin E. Intraluminal pressures during perfusion of the human colon in situ. Gastroenterology 1976; 70: 336-40

4 Edwards CA. Mechanisms of action of dietary fibre on small intestinal motility and absorption. 1990. In: Furda I, Brine CJ, eds. New developments in dietary fibre physiological and analvical aspects. New York: Plenus Press 95-104.

5 Kirwan WO, Smith AN, Mitchell WD, Falconer JD, Eastwood MA. Bile acids and colonic motility in the rabbit and human. Gut 1975; 16: 894-900.

6 Spiller RC, Brown ML, Phillips SF. Decreased fluid tolerance, accelerated transit and abnormal motility of the human colon accelerated transit and abnormal motility of the human col
induced by oleic acid. Gastroenterology 1986; $91: 100-7$.

7 induced by oleic acid. Gastroenterologv 1986; 91 : $100-7$. fatty acids on the motility of the rat colon in vitro. (iut 1991; fatty acids on

8 Englyst HN, Cummings JH. Simplified method for the measurement of total non-starch polysaccharides by gas liquid chromatography of consistent sugars as alditol acetates. Analyst 1984; 109: 937-42.

9 Walter DJ, Eastwood MA, Brydon WG, Elton RA. An experimental design to study colonic fibre fermentation in the rat. The duration of feeding. BrF N utr 1986; 55: $+65-79$.

10 Spiller GA, Chernoff MC, Hill RA, Gates JE, Nassar JJ, Shipley EA. Effect of purified cellulose, pectin and a low
residue diet on fecal volatile fatt acids, transit time and faecal weight in humans. Am f (Clin N'ut 1980; 33: 73+-9. ispaghula did not increase the water holding capacity of the faeces of rats when fed at dose. ${ }^{16}$ The effects of SCFAs (the major anions in the colon) on motility have not been well studied but have been shown to both produce contractions ${ }^{17}$ and inhibit these in different in vitro 
11 Adiotomre J, Eastwood MA, Edwards CA, Brydon WG Dietary fibre: in vitro methods which anticipate nutrition
and metabolic activity in humans. Am 7 Clin Nutr 1990; 52: and metabo

12 Kumar A, Kumar N, Vij JC, Sarin SK, Anand BS. Optimum dosage of ispaghula husk in patients with irritable bowel syndrome: correlation of symptom relief with whole gut transit time and stool weight. Gut 1987; 28: 1505

13 McNeil NI, Cummings JH, James PT. Short chain fatty acid absorption by the human large intestine. Gut 1978; 19: 819 22.

14 Ruppin H, Bar-meir S, Soergel KH, Wood CM, Schmitt MG. Absorption of short chain fatty acids by the colon. Gastroenterology 1980; 78: 1500-7.

15 Crump MH, Argenzio RA, Whipp SC. Effects of acetate on absorption of solute and water from the pig colon. Am $\mathcal{F}$ Vet Res 1980; 41: 1565-8.
16 Edwards CA, Bowen J, Brydon WG, Eastwood MA. The effects of ispaghula on rat caecal fermentation and stool effects of ispaghula on rat caecal fermentation and stool

17 output. Brf Nutr (in press).

Yajima T. Contractile effect of short chain fatty acids on the isolated colon of the rat. F Physiol 1985; 368: 667-78.

18 Svendsen P. Inhibition of cecal motility in sheep by volatile fatty acids. Nord Vet Med 1972; 24: 393-6.

19 Edwards CA, Brown S, Baxter AJ, Banister JJ, Read NW. Effect of bile acid on anorectal function in man. Gut 1989; 30: 383-6.

20 Roediger WEW. Utilisation of nutrients by isolated epithelial cells of the rat colon. Gastroenterology 1982; 83: 424-9.

21 Augeron C, Laboisse CL. Emergence of permanently differentiated cell clones in a human colonic cancer cell line after treatment with sodium butyrate. Cancer Res 1984; 44: 3961-9.

22 Tomlin J, Read NW. Laxative properties of plastic particles. $B M \mathcal{F}$ 1988; 297: 1175-6. 